\title{
CORRIGENDUM
}

\section{Decentralisation of long-term care in the Netherlands: the case of day care at green care farms for people with dementia - CORRIGENDUM}

doi: $10.1017 /$ So $144686 X_{13000937}$, published by Cambridge University Press 16 December 2013 .

The affiliation for Dr Lenneke Vaandrager was listed incorrectly in this paper.

The correct affiliations are listed below:

STÉPHANIE J. M. NOWAK*, CLAUDIA C. M. MOLEMA*, CAROLINE A. BAAN*, SIMON J. OOSTING $\dagger$, LENNEKE VAANDRAGER + , PETER HOP§ and SIMONE R. DE BRUIN*

* Centre for Nutrition, Prevention, and Health Services, National Institute for Public Health and the Environment, Bilthoven, The Netherlands.

$\dagger$ Animal Production Systems Group, Department of Animal Sciences, Wageningen University and Research Centre, The Netherlands.

\& Health \& Society Group, Department of Social Sciences, Wageningen University and Research Centre, The Netherlands.

$\S$ LEAS bureau voor zorgvernieuwing, Zoetermeer, The Netherlands.

We apologise to the readers for this error.

\section{Reference}

Nowak, S. J. M., Molema, C. C. M., Baan, C. A., Oosting, S. J., Vaandrager, L., Hop, P. and De Bruin, S. R. 2013. Decentralisation of long-term care in the Netherlands: the case of day care at green care farms for people with dementia. Ageing $\mathcal{E}$ Society, published online 16 December 2013, doi: 10.1017/So144686X13000937. 